\title{
Using the Cosmic Curriculum of Dr. Montessori Toward the Development of a Place-Based Indigenous Science Program
}

Nanette S. Schonleber, Department of Early Childhood Studies, Sonoma State University

Keywords: Montessori, Cosmic Curriculum, Hawaiian language immersion, Indigenous epistemology; culture-based science curricula; Anschauung educators

Abstract: Indigenous educators desire to use culturally restorative and decolonized pedagogies reflective of their own cultural values and beliefs in their science programs but have lacked models for how to start. They also often lack confidence in their ability to teach the sciences. This three-year qualitative case study used grounded theory methodology to discover (a) how Hawaiian language immersion (HLC) K-6 educators used Maria Montessori's Cosmic Curriculum for the creation of a science program based on Hawaiian epistemology and cultural values and (b) why the Cosmic Curriculum appealed to the HLC educators. Five key themes emerged: (a) the notion of creation as interconnected and relational, (b) an epistemological similarity regarding how people learn, (c) using timelines as organizing cognitive structures, (d) a focus on the natural sciences, and (e) the use of storytelling and key lessons to engage students. Participants stated that they felt successful in creating science curriculum and teaching the sciences as they adapted the above aspects of Dr. Montessori's Cosmic Curriculum. Future research should be conducted to discover if her Cosmic Curriculum can be adapted for use in other types of non-Montessori program and whether this kind of science program could encourage students to choose the sciences as a career choice.

In this paper, I describe how K-6 Hawaiian language immersion and culture-based (HLC) educators used Maria Montessori’s Cosmic Curriculum (Montessori, 1948/1991) as a scaffold to create and implement a culturally restorative and decolonized science program. The science program integrated Hawaiian cultural values with Western views of science. The HLC educators wanted their students to be able to pass state-mandated science evaluations while also becoming grounded in their own language and culture (Kelling \& Schonleber, 2011). The teachers also wanted to inspire their students to want to become scientists and leaders who could approach the future through the lens of their own Indigenous cultural perspective, epistemology, and experiences.

While there is a dearth of Indigenous scientists in the United States (Bang et al., 2018; Bernard \& Cooperdock, 2018; National Research Council, 2014), preschool through college ( $\mathrm{P}-16)$ science programs in the United 
States are still not inspiring enough students from Indigenous cultures to become scientists (Kahn et al., 2020; Nelson \& Madesen, 2018). According to Morgan et al., (2016), this race- and class-based inequity is detectable before kindergarten entry. It results from lack of access to a science curriculum utilizing the informal funds of knowledge and identity students bring with them from home and community (Esteban-Guitart \& Moll, 2014; Rice, 2020). In addition to the lack of a motivating science, technology, engineering, and mathematics (STEM) curriculum to which their students can relate, preschool through sixth-grade (P-6) teachers often lack adequate basic content knowledge and confidence to teach the sciences at all, no matter what curriculum they are using (Aslan et al., 2016; Blank, 2013; Mullis et al., 2020)

Teaching the sciences may be even more difficult for teachers wishing to teach an Indigenous perspective on the sciences. In addition to needing to know the science content for two knowledge systems, Indigenous educators also need to be able to function as cultural brokers for their students (Schonleber \& Kelling, 2018). Aikenhead (2001) stated that Indigenous students may feel disinterest because of a discrepancy between the values and mores of Western science traditions and the traditions and beliefs of Indigenous peoples. In Indigenous cultures, scientific knowledge is implicit within the activities of the culture. In Western cultures, scientific knowledge is a set of abstract principles and concepts devoid of context (Varghese \& Crawford, 2021).

Some HLC educators also have asserted the need for a curriculum to function as "a bridge between the past and the future." (Schonleber, 2011, p. 7) They view the Montessori approach as providing that bridge because of perceived overlaps in teaching strategies, values and beliefs, and a shared world view regarding the nature of the universe (Schonleber, 2011). Non-HLC Indigenous educators also have adapted the Montessori approach (Montessori, 1912/1964) for those same reasons (Holmes, 2018; Romero-Little, 2010). Unlike traditional schooling models with their one-size-fits-all curriculum, the Montessori approach emphasizes the need for education to be adapted to the time and place of the families and children in their own communities. Learning and teaching are holistic, grounded in both reality and relatedness, and focused on supporting the development of the whole person to be able to achieve their greatest potential (Montessori, 1912/1964).

\section{Purpose}

There were two purposes for this qualitative case study. One was to discover how a group of HLC kindergarten through sixth-grade (K-6) educators used Dr. Montessori's Cosmic Curriculum to create a science curriculum based on Hawaiian epistemology and cultural values. The other purpose was to discover why the HLC educators chose her Cosmic Curriculum. The connection between the Montessori approach and Indigenous education is known. However previous research has not explored a specific connection between the Cosmic Curriculum and the creation of an Indigenous science curriculum designed for students to be able to "walk in both worlds." (I. K. Kelling, personal communication, February 10, 2020)

\section{Theoretical Framework}

The study utilized sociocultural learning theory (John-Steiner \& Mahn, 1996; Vygotsky, 1978), which posits that learning is situated in a cultural context bounded by time and history. Learning occurs because of interplay between the environment and the individual, most often with the assistance of a more knowledgeable other. According to this theoretical perspective, the learning process is understandable only from the perspective of the child's social world (Vygotsky, 1978).

\section{The Montessori Approach}

The Montessori approach, with its well-operationalized and replicable pedagogy (Cossentino, 2005), has existed for more than 100 years (Chattin-McNichols, 1991). and there are over 20,000 public Montessori programs around the world (Center for Montessori in the Public Sector, 2019).

\section{From Medical Doctor to Peace Educator}

Dr. Montessori began her career as a medical doctor who focused on pediatric neurology (Lee, 2020). In this role, she made medical rounds in a local asylum where her young patients with neurological and cognitive disabilities lived. She had the insight that her patients were starved for stimulation and decided to find ways to help (Kramer, 1988). Dr. Montessori's research and discoveries inspired the formulation of a method of teaching and approach to learning she termed the Montessori Method (Montessori, 1912/1964). Dr. Montessori's Method began with an emphasis on sensory learning, access to 
the natural world, exercises of practical living, and an ordered and sequential set of didactic materials designed to spark children's interest and support optimal growth and development (Montessori, 1912/1964; 1914/1965). The Method evolved into a holistic view of education and hope for a more peaceful world (Montessori, 1949/1992).

\section{An Anschauung Educator}

Dr. Montessori was influenced by a group of Anschauung philosophers and educators dating back to Johann Heinrich Pestalozzi (1756-1827), Joseph Priestley (1733-1804), and Johann Friedrich Herbart (17761841). Anschauung educators believed that the spiritual and scientific worlds work together as one; they thought that theories of education should be based on observed facts, sensory knowledge, innate patterns of growth and development, and intuition (Takaya, 2003; Trudeau, 1984). From this perspective, how we know something is based on empirical information gained through all our senses. Our brain actively organizes and classifies sensory information according to perceived importance. Once classified, information becomes transformed into an internal mental model of the world. What we notice or pay attention to depends on our cultural, relational, developmental, and survival needs. From her clinical observations of children, Dr. Montessori believed this transformation occurred through close, sustained attention to whatever was of interest (Montessori, 1949/1994).

\section{From Anschauung Educator to the Cosmic Curriculum and Peace Education}

In 1939, the Theosophical Society invited Dr. Montessori to Adyar, India, to give a training program on the grounds of its compound. When Italy entered World War II on the side of the Germans, the Allied forces required Dr. Montessori to be interned in Kodaikanal, India, along with other enemy aliens from around the world (Trudeau, 1984). Parents asked Dr. Montessori to begin a school for the children within the compound, so she started a school for about 100 international students of all ages. Dr. Montessori held lessons outdoors in a large, open-air pavilion with the natural world surrounding them (Kahn, 1998; Trudeau, 1984). She finally had the luxury of time to reflect on her experiences and observations about children and life, and it was here in Kodaikanal that she more fully developed her Cosmic Curriculum. Lena Wicknamaratne, the Montessori teacher at Kodaikanal during that time, described the experience in an interview with Sister Christina Marie Trudeau in 1983 (Trudeau, 1984):

For the first time, [Dr. Montessori] . . began to see all of her basic cosmic background come true. The whole of the spiritual foundation of humankind, the spiritual unity of man, she could see that was true. For here were all these vastly different people... all this was combined in one melting pot with [Dr. Montessori's methods]. And [Dr.] Montessori saw the cosmic value of what she was saying because, despite the disparate backgrounds, all the children reacted basically the same way... and the trainees too. Putting education in a cosmic setting came there, in India, because of all these international and multi-aged children. (p. 119).

\section{Montessori's Cosmic Curriculum}

Dr. Montessori described her Cosmic Curriculum most thoroughly in her book, To Educate the Human Potential (1948/1991). As an integrated and place-based curriculum, the Cosmic Curriculum utilizes pedagogy capitalizing on developmental qualities found in 6-to-12year-olds. The curriculum provides a conceptual overview of the history of the universe, including Earth and all its living and nonliving components. The curriculum also provides a framework for learning the history of the universe through a series of five or six stories, complete with props and timelines to tie the stories together. The Great Lessons, as the stories with their props connected via timelines are sometimes called, are typically taught at the beginning of each year in Montessori Elementary classrooms. According to Duffy and Duffy (2002), the stories of the Great Lessons provide a way for students and teachers to emotionally connect to the material. Research on the power of healing and the use of stories in learning and teaching suggests that Dr. Montessori hit upon a powerful truth (Rosenthal, 2003; Weaver, 1994). Gulino and Shears (2018) state that he cognitive and perceptual processes used when people listen to a story make for richer connections and create a coherent narrative of life and situations. According to Boris (2017), telling stories is one of the most effective means of teaching, as the cognitive framework created by the stories helps us know how to respond emotionally to different situations. Stories also help us separate substantial amounts of information into manageable pieces so we can remember them 
Table 1

The Great Stories and Their Relationships to Western Sciences

\begin{tabular}{ll}
\multicolumn{1}{c}{ Great Story } & \multicolumn{1}{c}{ Western science } \\
\hline The Creation of the Universe & cosmology, astronomy, physics, chemistry \\
The Coming Into Being of Earth & geography, geology \\
biology, ecology & anthropology, sociology, archeology \\
The Coming of Life & linguistics \\
The Coming of Human Beings & mathematics \\
The Story of Communication in Signs & \\
The Story of Numbers &
\end{tabular}

Note. From Montessori Today: A Comprehensive Approach to Education From Birth to Adulthood, by P. P. Lillard, 1996, Schocken Books.

long enough to create long-term neural pathways (Gulino \& Shears, 2018). In a brilliant example of Miller's magical number seven (Miller, 1956), each of the Great Lessons connects to one or more of the sciences or a content area of the classroom, or both. The telling of the stories follows the sequence shown in Table 1.

The Cosmic Curriculum also provides a conceptual map, or framework for researching and learning any topic of interest through the sciences (see Figure 1). Students can independently or collaboratively study and learn about topics of personal interest while meeting state-mandated science standards. Teachers can immediately see where there are gaps in what students have chosen to research as well as in state standards. For example, if students are interested in learning about the complex system of life found within Hawaiian fishponds, they can organize their questions around the five perspectives in the

\section{Figure 1}

The Anticipatory Web Template

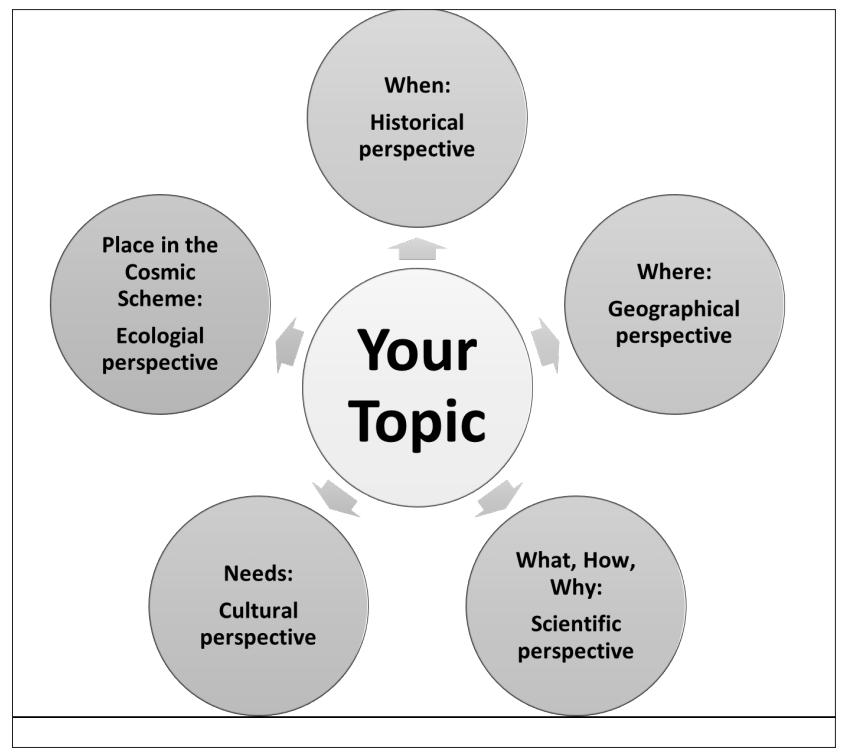

Note. Starting with the historical perspective and going clockwise, each bubble is for questions of (a) when, (b) where, (c) what, why, and how, (d) needs and relationships to humans, and (e) the role of the topic in the ecosystem. conceptual map shown in Figure 1. The five perspectives include a historical view, a geographical view, a cultural view, a "parts-to-the-whole" view and an integrated or ecological view. (Schonleber \& Kelling, 2018). With this framework, teachers who previously felt powerless to teach the sciences feel both empowered and excited to work with students to investigate topics within the sciences that are of interest to them (Kelling \& Schonleber, 2011). These cognitive frameworks work in multiple cultural contexts and with multiple knowledge systems. The stories change, according to culture and time, but the framework is consistent.

\section{Hawaiian Language Immersion and Culture-Based Education}

Before the arrival of Europeans in the late 1700s, Hawaiians had a well-organized system of both informal and formal learning (Chun, 2006; Osorio, 2002). When they were first exposed to the technology of the written word, they immediately recognized the value of the alphabet. By 1846, according to Wilson and Kamanā (2006), over 90\% of the Hawaiian population was literate; by the time of the overthrow of the Hawaiian Kingdom in 1893, however, the Hawaiian system of education had changed drastically. The Americans who overthrew the Hawaiian monarchy institutionalized assimilationist policies similar to those imposed on Native Americans and other Indigenous peoples (Osorio, 2002; Reyhner, 2017); in 1896, those same Americans banned the Hawaiian language. By the 1990s, only $4 \%$ of Hawaiian people considered themselves to be fluent speakers of the Hawaiian language (Wilson \& Kamanā, 2001).

In the 1970s, a movement to revitalize the Hawaiian language and culture included the creation of HLC schools. The core mission of HLC schools is to save the Hawaiian language from extinction and to support Hawaiian children in experiencing a sense of pride and belonging in their own culture. Beginning with the 'Aha Pünana Leo (language nest) program, the movement 
expanded in 1987 to include Ka Papahana Kaiapuni, a public-school, Hawaiian language immersion program (Wilson \& Kamanā, 2001). Today, there are 22 Papa Kaiapuni programs and nine public charter schools that focus on the Hawaiian culture or the Hawaiian language and culture (Hawai 'i State Department of Education, 2021). Scores from statewide tests of math, English, and science indicate student outcomes in these programs are equal to or better than those of their peers in conventional schooling systems (Wilson \& Kamanā, 2006).

\section{Montessori and Hawaiian Language Immersion Education}

Access to Montessori teacher education is not readily available outside private training institutions or within separate, stand-alone programs in a community college or university. This means that Montessori education is not well-known in other types of educational systems. In Hawai i between 1993 and 2003, a group of HLC educators completed between 225 and 600 hours of Montessori coursework as an integral part of their early childhood master's degree program. HLC educators immediately noticed similarities between their ancestors' perspectives on teaching and learning and Dr. Montessori's perspectives on teaching and learning. They often commented on the similarities.

\section{Method}

\section{Study Design}

Grounded theory methodology (Denzin \& Lincoln, 2011; Strauss \& Corbin, 1994) guided the overall design strategy of this qualitative case study. Grounded theory methodology is an analytic approach using a case perspective whereby theory derives from both inductive reason- ing and deductive analysis. Grounded theory methodology is also an appropriate research methodology when conducting research with Indigenous peoples (Elers, 2016; Wilson \& Baker, 2012).

\section{Participants}

The study took place at a kindergarten through grade 12 HLC school in Hawai 'i. Hawaiian activist parents and scholars founded the school with the goal of revitalizing the language and cultural values of the Hawaiian people. Like schools in other parts of the country that emphasize the culture and language of Indigenous peoples (Lipka \& Ilutsik, 1995), this school makes use of the cultural strengths of the Hawaiian culture and community. Here, children learn their cultural differences can be an asset (Meyer, 2003; Yamauchi, 2003). As one of the founders of the HLC movement said, there was "a need, an urgent need, to help to revitalize the language and the culture for all of Hawai 'i's people. Especially for the Hawaiian people, but not just for the Hawaiian people" (K. Kamanā, personal communication, May 5, 2005)

Participants included seven K-6 educators, and 60 $\mathrm{K}-6$ students. All seven educators who worked at the HLC program had their bachelor's degrees in Hawaiian studies or Hawaiian language. At the time of the study, four also had their master's degrees. The Kumu Alaka ' $i$ (teacher, guide [Pukui \& Elbert, 1986]) had a doctorate in educational administration. The experience of the school educators at the time of the study was just under 10 years, and the average educator age was 33 . The students' ages ranged from 5 to 12 years, and $92 \%$ were Hawaiian or part Hawaiian.

At the time the study began, the Kumu Alaka ' $i$ and I had known one another for 12 years. We worked collaboratively on this project, first informally and then formally, for

Table 2

Demographic Information for Teachers and Kumu Alakai

\begin{tabular}{lccclc}
\hline \multicolumn{1}{c}{ Pseudonym } & Age & $\begin{array}{c}\text { No. of years with } \\
\text { school }\end{array}$ & $\begin{array}{c}\text { No. of years } \\
\text { teaching }\end{array}$ & Ethnicity & Role \\
\hline Koalani & 32 & 7 & 14 & Not Hawaiian & Kumu Alakai \\
Anuenue & 34 & 0 & 2 & Hawaiian & K teacher \\
Ululani & 36 & 6 & 13 & Part Hawaiian & G1-2 teacher \\
Kanani & 30 & 5 & 8 & Part Hawaiian & G1-2 teacher \\
Mahina & 31 & 1 & 5 & Part Hawaiian & G3-4 teacher \\
Kanoe & 36 & 0 & 6 & Hawaiian & G5-6 teacher \\
Kalea & 49 & 0 & 18 & Hawaiian & K-G3-4 teacher \\
\hline
\end{tabular}

Note. All teachers were female, and all spoke Hawaiian. K = kindergarten; G1-2 = combined first and second grades; G3-4 = combined second and third grades; G5-6 = combined fourth and fifth grades. 
5 years. Three of the teachers had participated in an earlier study with me. See Table 2 for a summary of the demographic information for the teachers and the Kumu Alaka $i$.

\section{Procedure}

Procedures during our first year included the following steps:

- two 90-minute semistructured focus groups;

- two 6-hour workshops;

- two 4-hour teacher visits to schools and classrooms using approaches the teachers were interested in learning more about;

- three 90-to-120-minute individual classroom observations with coaching and consultation for each HLC teacher;

- twice-monthly in-service professional development meetings;

- the implementation of a pilot inquiry project by one of the HLC teachers.

Procedures during our second year started with the development and implementation of a 45-hour specialized summer course focused on introducing educators to the Montessori Cosmic Curriculum and framework and on building their confidence in their knowledge of traditional Hawaiian science concepts. After the semester commenced, there were five 90-to-120-minute classroom observations combined with individual coaching and consultations for each HLC teacher. There were twice-monthly in-service meetings as we implemented the inquiry projects in all the classrooms. At the end of the project, there was a final 30-minute teacher focus group, a final 30-minute conversation with the students of each classroom, and parent feedback.

\section{Ethics}

I obtained informed consent from all participants included in the study. To ensure participants' confidentiality and anonymity, I removed all identifying information from the transcripts, and I referred to participants according to identification codes. Teachers chose their own pseudonyms. This study received approval from the Institutional Review Board for the Rights of Human Subjects at my home institution, and I secured all data as required by the ethical recommendations of the American Psychological Association. No other permissions were required.

\section{Data Analysis}

I used the constant comparison method described by Strauss and Corbin (1994) for the qualitative data analysis. This qualitative method of analyzing data is the "data-analytic process whereby each interpretation and finding is compared with existing findings as it emerges from the data analysis" (Lewis-Beck et al., 2004. p. 2). I first coded data as received; these data were coded at the level of individual keywords or open codes using a lineby-line process, and later, as patterns emerged, as themes. The first open codes informed our future in-service sessions and interview questions and led to further readings of the literature to better understand the emerging categories. Through this iterative process, 15 initial categories emerged. Axial coding (Ezzy, 2002) led to five emergent themes and finally, from those five, one grounded theory emerged. This theme best connected and explained the other four themes, their elements, and their relationships with one another. The process concluded with member checks.

\section{Findings}

Five themes explained how learning about Dr. Montessori's Cosmic Curriculum supported the HLC educators in achieving an important goal. HLC educators wanted to be able to create a culturally restorative and decolonized science program that privileged and integrated deeply held Hawaiian cultural values while also accounting for the state-mandated science evaluations of their third-grade students' knowledge of Western science (Kelling \& Schonleber, 2011). They achieved that goal.

The first two themes answered the question of why the Montessori approach appealed to the HLC educators. They described (a) a holistic and relational world view shared by the two types of educators and (b) an empirical epistemology based on the beliefs that the spiritual and scientific worlds work together as one and that knowledge should be based on observed facts, sensory knowledge, innate patterns of growth and development, and intuition. What we notice or pay attention to depends on our cultural, relational, developmental, and survival needs. (Takaya, 2003; Trudeau, 1984).

The other three themes answered the question of how Dr. Montessori's Cosmic Curriculum supported the HLC educators in creating their culturally restorative and decolonizing science program. The three themes were (a) 
the use of a culturally important timeline as an organizing cognitive structure, (b) an emphasis on the natural world, and (c) the use of Dr. Montessori's Great Lessons to anchor the science curriculum.

\section{The Interconnectedness of All Creation: A Grounded Theory}

The grounded theory that best explained the other four themes was a similar world view about the interconnected and relational nature of the universe and our role in the cosmos. This theme best explicated the narrative and described a worldview that is shared by many Indigenous educators. It was also a worldview that Dr. Montessori subscribed to. Here, for example, is what she wrote about her Cosmic Plan.

All [things] are linked and have their place in the universe ... the stars, earth, stones, life of all kinds form a whole in relation to one another, and so close is this relation that we cannot understand a stone without some understanding of the great sun! No matter what we touch, an atom, or a cell, we cannot explain it without knowledge of the wide universe! What am I? What is the task of [people] in this wonderful universe? Do we live merely for ourselves, is there something more for us to do? (Montessori, $1948 / 1991$, p. 10)

Like other Indigenous educators, the HLC educators viewed everything in the universe as connected in a system of dynamic and reciprocal relationships (Cajete, 2000), and the idea of an integrated curriculum emphasizing the interconnectedness of everything made sense to them. An educator who had taken part in a previous study about the general connection between what Dr. Montessori wrote and believed and what HLC educators believed said:

What got [us], was that concept of the interconnectedness of all creation ... what [Dr.] Montessori called the Cosmic Plan. It [the Cosmic Plan] has Montessori's name to it, but the concepts are universal.... The beliefs and concepts that [Dr.] Montessori wrote down ... are what Indigenous people [like] our kūpuna [grandparents, (Pukui \& Elbert, 1986)] believe. This is what we felt was a match.

During the reflection after the class, another teacher said,
I was unconsciously integrating an integrated cultural perspective [all along] when I took the keiki [child, children (Pukui \& Elbert, 1986)] to a friend's nursery. We learned a chant to asking for water, learned about the water cycle, where the rain comes from, and went through each plant in the Kumulipo [origin, genesis, name of the Hawaiian creation poem consisting of 16 sections and over 2000 lines (Pukui \& Elbert, 1986)] from there [the Kumulipo] explained why there is a connection between plant and fish, why there are different variations of kalo [taro, an edible tuber and considered a staple of $\mathrm{Ha}$ waiian traditional foods (Pukui \& Elbert, 1986) with different fish names, and so forth. When the keiki learned the chant, they realized that words have power. [I] feel like I gained (and the keiki gained) perspective to make connections.

These two observations show the remarkable similarity of world view between the two educators, including the notion that everything is related and connected.

\section{The Montessori Approach Is so Tangible and Sensorial: A Shared Epistemology}

The second theme is an empirical epistemological perspective shared by both approaches. As described earlier, this perspective is based on the beliefs that both the spiritual and the scientific world work together as one and that knowledge should be based on observed facts, sensory knowledge, innate patterns of growth and development, and intuition. The connection to sensorial learning specifically relates to the element in knowledge involving sense awareness and to the need for patience and keeping observation as a necessary prerequisite for learning. Pestalozzi described this sense awareness as the foundation of all knowledge (Downs, 1975), and a hallmark of any early childhood Montessori classroom is the sensory education area of the prepared environment. Dr. Montessori's focus on sensorial learning never wavered in all the years she worked with children. In one of her last books, she wrote:

Our sensorial material provides a kind of guide to observation, for it classifies the impressions that each sense can receive: the colours, notes, noises, forms and sizes, touch-sensations, odors, and tastes. This undoubtedly is also a form of culture, for it leads 
us to pay attention both to ourselves and to our surroundings.... The senses, being explorers of the world, open the way to knowledge. (Montessori, 1949/1994, p. 183)

What resonated most for the $\mathrm{K}-4$ math specialist was the fact that Montessori education emphasizes sensorial knowledge based on empirical facts.

[The Montessori approach] is so tangible and... sensorial. And as Hawaiians ... that's what we can sit in the room and agree on.... Tangible things like, "This is how you do poi [the Hawaiian staff of life, made from cooked taro (Pukui \& Elbert, 1986)]." We might have a two-hour discussion on how you show aloha, but "This is poi. This is fish. This is how you clean [fish]." The tangibles. That's what we related to. Learning by reality.)

\section{Now Have a Logical Sequence to Follow: A Teaching Strategy Grounded in the Hawaiian Creation Story}

The third theme helps us understand how Dr. Montessori's Cosmic Curriculum was useful to the HLC educators in terms of pedagogical practices. The first strategy was the variety of timelines incorporated into the Cosmic Curriculum didactic materials. These timelines help organize students' understanding of the universe and their own place in the universe. For example, a timeline described in "The Long Black Strip" compares the length of time Earth has existed with the length of time humans have existed (Baker, 2011). These timelines are direct and active, so students find it easy and interesting to learn about the different eras with their corresponding plants and animals. Dr. Montessori used Western science as the basis of her timeline, but when the HLC teachers saw this didactic material, they at once made a connection to the Kumulipo, a Hawaiian creation chant consisting of 16 sections and more than 2,000 lines (Beckwith, 1951). Anuenue, the kindergarten teacher, said, about having a framework for her teaching,

As a result of [learning about using the Kumulipo as a curriculum timeline], I have a guide for my lessons for the entire school year. I never had this much guidance with my curriculum. With my unit plan, I will be more consistent and hopefully create smoother transitions between units as I now have a logical sequence to follow.
And at the end of the project, Mahina, the grades 3-4 teacher, said what was typical of responses by other educators: "I'm excited ... because I know this is what I've been lacking all these years teaching. Worried because I want to, and need to, make sure I've planned well enough for my students."

\section{"Learning About Sea Knowledge, For Example": A Focus on the Natural World}

This was the second of the three themes focused on pedagogical strategies. Both Dr. Montessori and the HLC educators advocate for teaching with an emphasis on caring for and understanding the natural world. Dr. Montessori was adamant about the necessity of connecting children with nature and of the caretaking role of humanity with regard to Earth (Montessori, 1948/1994). Her writings constantly referred to connecting children with the natural world. In The Discovery of the Child (Montessori, 1948/1967), for example, Dr. Montessori wrote a whole chapter on the need for children to be connected with the natural world. In her book, From Childhood to Adolescence (Montessori, 1948/1994), she wrote,

There is no description, no image in any book that is capable of replacing the sight of real trees, and all the life to be found around them, in a real forest. Something emanates from those trees which speaks to the soul, something no book, no museum is capable of giving. (p. 19)

This resonated deeply with the HLC educators. A regular part of their curriculum was to take the children to work at the 800-year-old human-designed fishpond or the 10 ' $i$ kalo (taro patch [Pukui \& Elbert, 1986]) to garden. One educator said in an interview for an earlier project,

The relationship between us as humans and nature, and what [Dr.] Montessori talked about: How there's that relationship [with nature] and how having that garden is important. We try to cultivate that, and build sustainability, especially in the Hawaiian immersion charter schools where [the children and teachers] go to visit the lo ' $i$ kalo [taro field (Pukui \& Elbert, 1986)] and learn about farming and being able to take care of themselves.

The embedded nature of humans and the natural world within the Cosmic Curriculum at once captured her interest. Another teacher agreed: 
The learning environment is not only in the classrooms, but outside too. Emphasizing physical activity and learning about sea knowledge, for example. Fruit bearing knowledge. You go down to the ocean, learn about your life skills down at the ocean, and connect with trying to bring back the Hawaiian literature.

\section{"From Those Stories and Those Concepts You Can Get Everything" Teaching by Telling Stories}

This was the third of three themes that related to shared pedagogical strategies, and it involves the power of storytelling. Dr. Montessori advocated the use of stories for the 6- to-12-year-old child, saying there was a need to teach this age through the use of imagination and the judicious use of stories and tales. She described,

To interest the students in the universe, we must not begin by giving them elementary facts about it, to merely make them understand its mechanisms, but start with far loftier notions of a philosophical manner.... Here we may usefully call to aid some myths or fairy tales, but they must be such as symbolize truths of nature, not wholly fantastic.... Life is one of the creative forces of the world $\ldots$ and has the power to acquire and retain impressions. (Montessori, 1948/1991, pp. 28-29).

Indigenous peoples, including the Native Hawaiians, have always used stories to teach, to inform, and to instruct (Datta, 2017), so the anchoring of Dr. Montessori's Cosmic Curriculum to stories was a natural match. A kindergarten through fourth-grade math specialist described how the teachers used the content of the Kumulipo to integrate their science curriculum. This teacher also had previously worked with the grade 5-6 teacher.

From those stories and from those concepts you can get everything. From the science to the politics, everything can come out of that ... the Kumulipo says it all. For example, when you learn at this wā [era, epoch, genesis (Pukui \& Elbert, 1986)] or this age of the Kumulipo, talking about certain plants and animals, well, that is where [the] science learning comes in. And when you reach the kanaka [human being (Pukui \& Elbert, 1986)] stage, that's where the politics side could come in, so we could have tied in a lot more academics. You could even get in math in there.
One of the other teachers spoke of what she saw as the important practice of teaching students by starting with the stories of their own place and then extending from the stories to more abstract concepts related to the different content areas such as history, science and language arts. She and the others then showed me children's books that one of the high school students created. It was all stories about the area: the plants, the animals, the reasons for the names of particular places. The teacher went on:

You know [the] Kumulipo project? The teacher worked with the third graders for research, and she... used the Montessori research approach where they had to identify "Where does [the thing being studied] live, what's its name, characteristics, the interesting facts about it, what it eats." You know, some of the basic research questions that Montessori [education] already does with the cards and charts of the animal kingdom. Since we had translated the [cards and charts of the animal kingdom] already, [the children] would do the research, and it wasn't actually that they had to read everything - they just had to look at the main points. And then later on they would put the main points into sentences, in their own grammar. And then the teacher would help with the grammar. So we had science, history, and language arts.

Using the three pedagogical strategies described above, in combination with a relational and connected worldview and congruent epistemology, provided the HLC educators with the tools to create what they needed: a decolonized science curriculum grounded in Hawaiian epistemology and a relational and interconnected perspective. Using the Cosmic Curriculum as inspiration also supported the HLC educators in this study to successfully incorporate Western science as part of the curriculum without dominating the curriculum. At the conclusion of this project, both teachers and students experienced a surge in confidence in their ability to do science in a culturally restorative and decolonizing manner, while also learning the science content needed so that students could do well on state-mandated exams.

\section{Discussion}

This study aimed to explore how and why HLC educators used Dr. Montessori's Cosmic Curriculum in their K-6 HLC classrooms to support their students in learn- 
ing how to think like scientists; how to use the culture and knowledge systems of their ancestors in building their understandings of STEM; and how to support their keiki in wanting to become scientists. To feel excited about the prospects of becoming scientists, a rich, direct, culturally restorative curriculum and decolonizing pedagogy needs to be employed by teachers who feel confident in their ability to teach from an Indigenous perspective what the Western world calls the sciences (Cajete, 2000; Cartier, 2019). These same teachers need to know that mainstream scientists will respect rather than exploit them for their cultural scientific knowledge (Green, 2021; Greenburg, 2020; James, 2001; Morris, 2020).

The results revealed that the HLC teachers related to Dr. Montessori's Cosmic Curriculum because of a congruence in epistemology (Meyer, 2001; Montessori, 1948/1991) and a shared philosophical cosmology in which the universe functions as a relational and interconnected whole. The HLC educators primarily used three teaching strategies of the Cosmic Curriculum as an inspiration for building their own HLC science curriculum. These three strategies were: (a) the use of timelines to understand the natural world, (b) the use of stories and storytelling, and (c) a focus on the natural world. Through the use of these three strategies they were able to use their own cultural experiences and understandings to create a science program that was culturally restorative and included content that the students needed so they could pass state-mandated science tests.

\section{Limitations}

This study was bounded by time and circumstance and cannot be generalized. In addition, I had worked with the Kumu Alaka ' $i$ and three of the teachers in the past; the teachers and the Kumu Alaka 'i may have felt intimidated or unwilling to share their true feelings. I attempted to mitigate this limitation by triangulating the data with samples of student work and student interviews and conducting a confidential member check at the end of the study.

\section{Conclusion}

The HLC educators felt successful using Dr. Montessori's Cosmic Curriculum as a scaffold to create their own culturally based science curriculum. Further research on the efficacy of using the Cosmic Curriculum as a scaffolding device with non-Montessori educators would help answer questions about whether it is possible to use the Cosmic Curriculum with educators who do not share the epistemology and cosmology philosophy of Dr. Montessori. Longitudinal studies of student change in attitudes about careers in the sciences and a sense of stewardship toward Earth would also be useful in discovering whether and how the use of the Cosmic Curriculum outside the Montessori ecosystem would work to increase interest in the sciences by Indigenous students.

\section{Author Information}

Nanette (Sheri) Schonleber is an associate professor in the Department of Early Childhood Studies at Sonoma State University. Address correspondence concerning this article to Nanette S. Schonleber, Department of Early Childhood Studies, Sonoma State University, 1801 E. Cotati Rd., Rohnert Park, CA 94928.

Email: schonleb@sonoma.edu

\section{References}

Aikenhead, G. (2001, September). Integrating Western and Aboriginal science: Cross-cultural science teaching. Research in Science Education, 31, 337-355. https://doi.org/10.1023/A:1013151709605

Aslan, D., Tąs, I., \& Oğul, I. G. (2016). Pre- and in-service preschool teachers' science teaching efficacy beliefs. Educational Research and Reviews, 11(14). https://files.eric.ed.gov/fulltext/EJ1108207.pdf

Baker, I. (2011). The long black strip: A lesson in humility. Montessori Services. https://www.montessoriservices.com/ideas-insights/the-long-black-strip

Bang, M., Marin, A., \& Medin, D. (2018, Spring). If indigenous peoples stand with the sciences, will scientists stand with us? Daedalus, 147(2), 148-159. http://doi.org/10.1162/DAED_a 00498

Beckwith, M. W. (1951). The Kumulipo: A Hawaiian creation chant. http://www.sacred-texts.com/pac/ku/

Bernard, R. E., \& Cooperdock, E. H. G. (2018, April 30). No progress on diversity in 40 years. Nature Geoscience, 11, 292-295. https://doi.org/10.1038/s41561-018-0116-6

Blank, R. K. (2013). Science instructional time is declining in elementary schools: What are the implications for student achievement and closing the gap? Science Education, 97(6), 830-847. https://doi.org/10.1002/sce.21078 
Boris, V. (2017, December 20). What makes storytelling so effective for learning? Harvard Business Publishing. https://www.harvardbusiness.org/what-makes-storytelling-so-effective-for-learning/

Cajete, G. A. (2000). Native science: Natural laws of interdependence. Clearlight Publishers.

Cartier, K. M. S. (2019, December). Keeping Indigenous science knowledge out of a colonial mold. Eos, 100. https://doi.org/10.1029/2019EO137505.

Center for Montessori in the Public Sector. (2019). Montessori schools around the world. https://www.public-montessori.org/montessori/

Chattin-McNichols, J. (1991). The Montessori controversy. Delmar.

Chun, M. N. (2006). A 'o: Educational traditions. University of Hawai' i Curriculum Research \& Development Group.

Cossentino, J. (2005, February). Ritualizing experience: A non-Montessorian view of the Montessori Method. American Journal of Education, 111(2), 211-244. http://doi.org/10.1086/426838

Datta, R. (2017). Traditional storytelling: An effective Indigenous research methodology and its implications for environmental research. AlterNative: An International Journal of Indigenous Peoples, 14(1), 35-44. http://doi.org/10.1177/1177180117741351

Denzin, N. K., \& Lincoln, Y. S. (Eds.). (2011). Handbook of qualitative research (4th ed.). Sage.

Downs, R. B. (1975). Heinrich Pestalozzi, father of modern pedagogy. Twayne Publishers.

Duffy, M., \& Duffy, D. (2002). Children of the universe: Cosmic education in the Montessori elementary classroom. Parent Child Press.

Elers, S. (2016, June). Refuting Denzin's claims: grounded theory and indigenous research. Grounded Theory Review, 2(16). http://groundedtheoryreview. com/2016/12/19/refuting-denzins-claims-grounded-theory-and-indigenous-research/

Esteban-Guitart, M., \& Moll, L. C. (2014). Funds of identity: A new concept based on the Funds of Knowledge approach. Culture and Psychology, 20(1), 31-48. https://doi.org/10.1177/1354067X13515934

Ezzy, D. (2002). Qualitative analysis: Practice and innovation. Routledge.

Frierson, P. R. (2014). Maria Montessori's epistemology. British Journal for the History of Philosophy, 22(4), 767-791.

http://doi.org/10.1080/09608788.2014.960794
Green, V. (2021). How to include Indigenous researchers and their knowledge. Nature, 589, 315-317. https:// www.nature.com/articles/d41586-021-00022-1

Greenburg, A. (2020, September 11). An indigenous bioethicist on CRISPR and decolonizing DNA. PBS Online. NOVA Newsletter. https://www.pbs.org/ wgbh/nova/article/bioethics-crispr-indigenous-genome/

Gulino, P., \& Shears, C. (2018). The science of screenwriting: The neuroscience behind storytelling strategies. Bloomsbury Academic.

Hawai'i State Department of Education. (2021). Hawaiian language immersion program. https://www. hawaiipublicschools.org/TeachingAndLearning/ StudentLearning/HawaiianEducation/Pages/translation.aspx

Holmes, C. C. (2018). Introduction of Montessori education to a remote Indigenous early childhood program: A study of the ways in which Aboriginal students respond. Journal of Montessori Research, 4(2), 33-60. https://doi.org/10.17161/jomr.v4i2.6715

James, K. (2001). Fires need fuel: Merging science education with American Indian needs. In K. James (Ed.), Science and Native American communities: Legacies of pain, visions of promise (pp. 1-8). University of Nebraska Press.

John-Steiner, V., \& Mahn, H. (1996). Sociocultural approaches to learning and development: A Vygotskian framework. Educational Psychologist, 31(3/4), 191-206. https://doi.org/10.1080/00461520.1996.9653266

Kahn, B., Robbins, C., \& Okrent, A. (2020). Science and engineering indicators 2020: The state of U.S. science and engineering (NSB-2020-1). National Science Foundation. https://ncses.nsf.gov/pubs/nsb20201/

Kahn, D. (1998). The Kodaikanal experience: KahnMontessori interview. The NAMTA Journal, 23(2), 34-42.

Kelling, I. K., \& Schonleber, N. S. (2011). He 'ike pāpālua o ke ao me ka pō: Teaching science in a Hawaiian cultural context. Hülili: Multidisciplinary Research on Hawaiian Well-Being, 7, 223-258.

Kramer, R. (1988). Maria Montessori: A biography. Perseus Books.

Lee, S. F. (2020). Maria Montessori: A complex and multifaceted historiographical subject. American Psychological Association, 20(2), 201-209. https://doi.org/10.1037/hop0000150 
Lewis-Beck, M. S., Bryman, A., \& Futing Liao, T. (2004). Constant comparison. The SAGE encyclopedia of social science research methods (Vols. 1-0). Sage.

Lipka, J., \& Ilutsik, E. (1995). Negotiated change: Yup'ik perspectives on indigenous schooling. The Bilingual Research Journal, 19(1), 195-207. https://doi.org/10.1080/15235882.1995.10668600

Meyer, M. A. (2001). Our own liberation: Reflections on Hawaiian epistemology. The Contemporary Pacific, 13(1), 124-148. https://www.jstor.org/stable/23718511

Meyer, M. A. (2003). Ho 'oulu: Our time of beginning. 'Ai Pōhaku Press.

Miller, G. A. (1956). The magical number seven, plus or minus two: Some limits on our capacity for processing information. Psychological Review, 101(2), 343-352.

Montessori, M. (1964). The Montessori Method. Schocken Books. (Original work published 1912)

Montessori, M. (1965). Dr. Montessori's own handbook: A short guide to her ideas and materials. Schocken Books. (Original work published 1914)

Montessori, M. (1967). The discovery of the child. Clio Press. (Original work published 1948)

Montessori, M. (1991). To educate the human potential. Kalakshetra Press. (Original work published 1948)

Montessori, M. (1994). From childhood to adolescence. Clio Press. (Original work published 1948)

Montessori, M. (1992). Peace and education. Clio Press. (Original work published 1949)

Montessori, M. (1994). The absorbent mind. Henry Holt and Company. (Original work published 1949)

Morgan, P. L., Farkas, G., Hillemeier, M. M., \& Maczuga, S. (2016). Science achievement gaps begin very early, persist, and are largely explained by modifiable factors. Educational Researcher, 45(1), 18-35. https://doi.org/10.3102/0013189X16633182

Morris, A. (2020, November 24). "Lifting up native science." Northwestern University McCormick School of Engineering. Engineering News. https://www.mccormick.northwestern.edu/news/articles/2020/11/ lifting-up-native-science-josiah-hester.html

Mullis, I. V. S., Martin, M. O., Foy, P., Kelly, D. L., \& Fishbein, B. (2020). TIMSS 2019 international results in mathematics and science. TIMSS \& PIRLS International Study Center. https://timssandpirls.bc.edu/ timss2019/international-results/
National Research Council. (2014). Furthering America's research enterprise. The National Academies Press.

Nelson, D. J., \& Madesen, L. D. (2018). Diversity in materials science and engineering: Representation of Native Americans in US science and engineering. MRS Bulletin, 43(5), 379-383. https://doi.org/10.1557/mrs.2018.108

Osorio, J. K. (2002). Dismembering Lähui: A history of the Hawaiian nation to 1887. University of Hawai $i$ Press.

Pukui, M. K., \& Elbert, S. H. (1986). Hawaiian dictionary: Hawaiian-English, English-Hawaiian, revised and enlarged edition. University of Hawai ' i Press.

Reyhner, J. (2017). Affirming identity: The role of language and culture in American Indian education. Cogent Education, 4(1). https://doi.org/10.1080/2331186X.2017.1340081

Rice, M. (2020). Honoring indigenous children's ways of knowing. In J. Reyhner, J. Martin, L. Lockard, \& W. S. Gilbert. (Eds.). Honoring our students (pp. 1-23). Northern Arizona University.

Romero-Little, M. E. (2010). How should young Indigenous children be prepared for learning? A vision of early childhood education for Indigenous children. Journal of American Indian Education, 49(1/2), 7-27. https://www.jstor.org/stable/43608587

Rosenthal, G. (2003). The healing effects of storytelling: On the conditions of curative storytelling in the context of research and counseling. Qualitative Inquiry, 9(6), 915-930. https://doi.org/10.1177/1077800403254888

Schonleber, N. S. (2011). Hawaiian culture-based education and the Montessori approach: Overlapping teaching practices, values, and worldview. Journal of American Indian Education, 50(3), 5-25. https://www.jstor.org/stable/43608610

Schonleber, N. S., \& Kelling, I. K. (2018). Creating a culturally responsive $\mathrm{K}-3$ science curriculum: Teachers as cultural brokers. International Journal of Early Childhood Education, 24(1), 67-92. https:// www.kci.go.kr/kciportal/landing/article.kci?arti id=ART002368412

Strauss, A., \& Corbin, J. (1994). Grounded theory methodology: An overview. In N. K. Denzin \& Y. S. Lincoln (Eds.), Handbook of qualitative research (pp. 1-18). Sage. 
Takaya, K. (2003). The method of Anschauung: From Johann H. Pestalozzi to Herbert Spencer. The Journal of Educational Thought (JET)/ Revue De La Pensée Éducative, 37(1), 77-99. https://www.jstor.org/stable/23767177

Trudeau, C. M. (1984). Montessori's years in India. Hawai $i$ Printing.

Varghese, J., \& Crawford, S. S. (2021). A cultural framework for Indigenous, local, and science knowledge systems in ecology and natural resource management. Ecological Monographs, 91(1). Article e01431. https://esajournals.onlinelibrary.wiley.com/doi/ epdf/10.1002/ecm.1431

Vygotsky, L. S. (1978). Mind in society: The development of higher psychological processes. Harvard University Press.

Weaver, M. C. (Ed.). (1994). Tales as tools: The power of story in the classroom. The National Storytelling Press.

Wilson, D., \& Baker, M. (2012). Bridging two worlds: Maori mental health nursing. Qualitative Health

Research, 22(8), 1073-1082. https://doi.org/10.1177/1049732312450213
Wilson, W. H., \& Kamanā, K. (2001). Mai Loko Mai O Ka 'I 'ini: Proceeding from a dream: The 'Aha Pūnana Leo connection in Hawaiian language revitalization. In L. Hinton \& K. Hale (Eds.), The green book of language revitalization in practice (pp. 147-176). Academic Press.

Wilson, W. H., \& Kamanā, K. (2006). "For the interest of the Hawaiians themselves": Reclaiming the benefits of Hawaiian-medium education. Hūlili: Multidisciplinary Research on Hawaiian Well-Being, 3(1), 153-181. http://www.ulukau.org/elib/collect/hulili06/index/assoc/D0.dir/doc152.pdf

Yamauchi, L. A. (2003). Making school relevant for atrisk students: The Wai' anae High School Hawaiian Studies Program. Journal of Education for Students Placed At Risk, 8(4), 379-390. https://doi.org/10.1207/S15327671ESPR0804_1 